\title{
Sistem Pendukung Keputusan Pemilihan Peminatan Program Studi Teknik Informatika Menggunakan Metode SAW
}

\author{
Triana Elizabeth $^{1}$, Tinaliah ${ }^{2}$ \\ ${ }^{1}$ Prodi Sistem Informasi STMIK GI MDP, Palembang \\ ${ }^{2}$ Prodi Manajemen Informatika AMIK MDP, Palembang \\ e-mail: ${ }^{1}$ trianaelizabeth@mdp.ac.id, ${ }^{2}$ tinaliah@mdp.ac.id
}

\begin{abstract}
Abstrak
Berdasarkan kurikulum program studi Teknik Informatika, dapat diketahui bahwa disemester 5mahasiswa program studi teknik informatika STMIK XYZ diwajibkan untuk mengambil mata kuliah pilihan berdasarkan peminatan yang telah disediakan.Tujuan dari peminatan adalahagar mahasiswa lulusan Program Studi Teknik Informatika STMIK XYZ memiliki kompetensi yang mendukung mereka untuk melanjutkan kuliah ke tingkat yang lebih tinggi (S2 atau S3) serta memiliki kompetensi kerja yang mendukung mereka ketika mereka lulus kuliah.Permasalahan yang sering terjadi adalah para mahasiswa sulit menentukan peminatan yang akan diambil. Oleh sebab itu, dibutuhkan suatu sistem pendukung keputusan yang dapat membantu para mahasiswa program studi Teknik Informatika STMIK XYZ mengambil keputusan peminatan apa yang akan mereka pilih.Sistem pendukung keputusan ini menerapkan metode Fuzzy Multiple Attribute Decission Making (FMADM) dan metode Simple Additive Weighting (SAW). Pembuatan sistem pendukung keputusan ini menggunakan aplikasi Netbeans IDE 8.2 dan MySQL sebagai databasenya.
\end{abstract}

Kata kunci-Fuzzy Multiple Decision Making (FMADM), Simple Additive Weighting (SAW), Netbeans IDE 8.2, MySQL

\begin{abstract}
Based on the Informatics Engineering study program curriculum, it can be seen that in the 5th semester students are required to take elective courses based on specialization provided. The purpose of specialization is for graduate students to have competencies that support them to continue their studies to a higher level (S2 or S3) and have work competencies that support them when they graduate from college. The problem is that it is difficult to determine the specialization that will be taken.Therefore, a decision support system is needed that can help STMIK XYZ Informatics Engineering students decide what they will choose. This decision support system applying Decission Fuzzy Multiple Attribute Making (FMADM) and Simple Additive weighting method (SAW). This decision support system design uses the Netbeans IDE 8.2 application and MySQL as the database.
\end{abstract}

Keywords-Fuzzy Multiple Decision Making (FMADM), Simple Additive Weighting (SAW), Netbeans IDE 8.2, MySQL

\section{PENDAHULUAN}

$\mathrm{M}$ ata kuliah merupakan satuan pelajaran yang diajarkan di perguruan tinggi. Salah satu program studi yang dimiliki oleh STMIK XYZ adalah Teknik Informatika. [1]Visi dari program studi Teknik Informatika STMIK XYZ adalah menjadi program studi Teknik Informatika unggulan di tingkat nasional dan dikenal di tingkat internasional serta mampu 
menjawab tantangan perkembangan teknologi informasidan komputer di tahun 2028. [1]Misi dari program studi Teknik Informatika STMIK XYZ adalah menyelenggarakan program pendidikan tinggi dan penelitian terbaik di bidang informatika melalui penerapan sistem penjaminan mutu terpadu, pengembangan kurikulum akademik yang dinamis dan adaptif didukung oleh SDM berkualitas, fasilitas pendidikan dengan kualitas terbaik, serta menyelenggarakan pengabdian pada masyarakat guna peningkatan kualitas hidup masyarakat. Salah satu yang dimiliki oleh program studi Teknik Informatika untuk mencapai visi dan misinya, adalah kurikulum yang berbasis KKNI (Kerangka Kualifikasi Nasional Indonesia). [2] KKNI adalah kerangka penjenjangan kualifikasi sumber daya manusia yang menyetarakan sektor pendidikan dengan sektor pelatihan dan pengalaman kerja yang bertujuan untuk menghasilkan sumber daya manusia yang bermutu dan produktif.

Berdasarkan kurikulum program studi Teknik Informatika, dapat diketahui bahwa di semester 5, mahasiswa program studi teknik informatika STMIK XYZ diwajibkan untuk mengambil mata kuliah pilihan berdasarkan peminatan yang telah disediakan. Peminatan yang disediakan ada 3 yaitu: pengembangan game dan mobile platform, komputasi ilmiah dan yang terakhir adalah jaringan komputer. Tujuan dari peminatan adalah agar mahasiswa lulusan Program Studi Teknik Informatika STMIK XYZ memiliki kompetensi yang mendukung mereka untuk melanjutkan kuliah ke tingkat yang lebih tinggi (S2 atau S3) serta memiliki kompetensi kerja yang mendukung mereka ketika mereka lulus kuliah.

Permasalahan yang sering terjadi adalah para mahasiswa sulit menentukan peminatan yang akan diambil. Biasanya mahasiswa mengambil peminatan dengan mempertimbangkan nilai-nilai mata kuliah yang telah mereka dapatkan pada semester sebelumnya yaitu pada nilainilai pada semester 1,2,3 dan semester 4. Pada beberapa kasus, cukup banyak mahasiswa yang memiliki nilai yang baik untuk setiap mata kuliah sehingga menyulitkan mereka untuk mengambil keputusan. Kasus lain adalah banyak mahasiswa yang mendapatkan nilai cukup bahkan pas-pas an di hampir semua mata kuliah sehingga juga menyulitkan mahasiswa untuk mengambil keputusan peminatan apa yang akan mereka ambil. Oleh sebab itu, dibutuhkan suatu sistem pendukung keputusan yang dapat membantu para mahasiswa program studi Teknik Informatika STMIK XYZ mengambil keputusan peminatan apa yang akan mereka pilih. Sistem pendukung keputusan ini akan menghasilkan informasi bagi mahasiswa peminatan apa yang sebaiknya mereka pilih berdasarkan nilai-nilai mata kuliah terkait. Sistem pendukung keputusan ini menerapkan metode Fuzzy Multiple Attribute Decission Making (FMADM) dan metode Simple Additive Weighting (SAW). Pembuatan sistem pendukung keputusan ini menggunakan aplikasi Netbeans IDE 8.2 dan MySQL sebagai databasenya.

\subsection{Fuzzy Multiple Attribute Decission Making (FMADM)}

[3] Fuzzy Multiple Attribute Decision Making (FMADM) adalah suatu metode yang digunakan untuk mencari alternatif dengan kriteria tertentu. Inti dari FMADM adalah menentukan nilai bobot untuk setiap atribut, kemudian dilanjutkan dengan proses perankingan yang sudah diberikan. Pada dasarnya ada 3 pendekatan untuk mencari bobot atribut, yaitu: pendekatan subyektif, obyektif dan pendekatan integrasi antara subyektif dan objektif. Pendekatan subyektif, nilai bobot ditentukan berdasarkan subyektifitas dari para pengambil keputusan, sehingga beberapa faktor dalam proses perankingan alternatif bisa ditentukan secara bebas. Sedangkan pada pendekatan obyektif, nilai bobot dihitung secara matematis sehingga mengabaikan subyektifitas dari pengambil keputusan.

\subsection{SAW (Simple Additive Weighting)}

[4] Konsep dasar metode SAW adalah mencari penjumlahan terbobot dari rating kinerja pada setiap alternatif pada semua aribut. Metode SAW membutuhkan proses normalisasi matriks

Elizabeth, et, al (Sistem Pendukung Keputusan Pemilihan Peminatan Program Studi Teknik Informatika Menggunakan Metode SAW) 
keputusan (X) ke suatu skala yang didapat diperbandingkan dengan semua rating alternatif yang ada. Formula untuk melakukan normalisasi sebagai berikut:

$$
r_{i j}=\left\{\begin{array}{c}
\frac{X_{i j}}{\text { MinX } X_{i j}}, j i k a j \text { adalah atribute keuntungan (benefit) } \\
\frac{\text { Max } X_{i j}}{X_{i j}}, \text { Jika } j \text { adalah atribute biaya (cost) }
\end{array}\right.
$$

Keterangan:

Max $X_{i j}=$ Nilai terbesar dari setiap kriteria i

Min $\mathrm{X}_{\mathrm{ij}}=$ Nilai terkecil dari setiap kriteria $\mathrm{i}$

$\mathrm{X}_{\mathrm{ij}} \quad=$ Nilai atribut yang dimiliki dari setiap kriteria

Benefit $=$ jika nilai terbesar adalah terbaik

Cost $=$ jika nilai terkecil adalah terbaik

Sedangkan nilai preferensi untuk setiap alternatif (Vi) dapat dihitung dengan rumus sebagai berikut:

Keterangan:

$$
v_{i}=\sum_{j=1}^{n} w_{j} r_{i j}
$$

$\mathrm{v}_{\mathrm{i}}=$ Ranking untuk setiap alternatif

$\mathrm{w}_{\mathrm{j}}=$ Nilai bobot ranking (dari setiap kriteria)

$\mathrm{r}_{\mathrm{ij}}=$ Nilai rating kinerja ternormalisasi

Nilai $V_{i}$ yang lebih besar mengindikasikan bahwa Alternatif $A_{i}$ lebih terpilih. Keunggulan dari metode SAW terletak pada kemampuannya dalam melakukan penilaian secara lebih tepat karena didasarkan pada nilai kriteria dan bobot tingkat kepentingan yang dibutuhkan. Selain itu, metode SAW dapat menyeleksi alternatif terbaik dari sejumlah alternatif yang ada kemudian dilakukannya proses perankingan yang jumlah nilai bobot dari semua kriteri dijumlahkan setelah menentukan nilai bobot dari setiap kriteria.

\subsection{Penelitian Terdahulu}

[5] Penelitian yang dilakukan oleh Yumarlin MZ adalah membuat sistem pendukung keputusan konsentrasi dan peminatan prodi teknik informatikaUniversitas Janabadra Yogyakarta.Permasalahan yang melatari penelitian ini adalah adanya berbagai kendala dalam menentukan konsentrasi dan peminatan yang sesuai dengan kriteria dan banyaknya mahasiswa hanya ikut ikutan temanya dalam menentukan peminatan serta kurangnya kepercayaan diri dengan kemampuan yang dimiliki. Model yang digunakan dalam penelitian ini adalah Fuzzy Multiple Attribute Decision Making (FMADM) dengan menggunakan metode SAW. Hasil dari penelitian ini adalah sistem pengambilan keputusan dengan menggunakan FMADM dengan metode SAW untuk menentukan konsentrasi dan peminatan program studi teknik informatika Universitas Janabadra Yogyakarta berdasarkan nilai-nilai dari semester 1 sampai semester 4 terhadap konsentrasi dan peminatan yang sesuai.

[6] Penelitian yang dilakukan oleh Muhammad Ibrohim dan Sumiati adalah membuat Sistem pendukung keputusan untuk menentukan penerima beasiswa menggunakan metode SAW. Permasalahan yang melatari penelitian ini adalah banyaknya jumlah mahasiswa yang mengajukan beasiswa sedangkan jumlah beasiswa yang tersedia terbatas, sehingga memyulitkan dalam pemilihan mahasiswa mana yang benar-benar pantas mendapatkan beasiswa. Kriteria yang digunakan dalam penelitian ini adalah indeks prestasi akademik, penghasilan orang tua, jumlah saudara kandung, semester, dll. Metode SAW dipilih dalam penelitian ini karena metode 
ini mampu memilih alternatif terbaik dari beberapa alternatif yang nantinya alternatif yang terbaik merupakan mahasiswa yang akan menerima beasiswa. Penelitian ini dilakukan dengan mencari bobot nilai untuk masing-masing atribut, kemudian dilakukan proses peringkat yang akan menentukan alternatif yang optimal.

[7] Penelitian yang dilakukan oleh Adi Suwarno berjudul perbandingan metode AHP dengan metode MADM Topsis untuk menentukan mata kuliah peminatan bagi mahasiswa. Penelitian ini dilakukan untuk mengkaji penelitian yang telah dilakukan oleh Ramdani pada tahun 2014 yang berjudul penerapan metode AHP dalam mendukung keputusan untuk memilih peminatan bagi mahasiswa STMIK Bani Saleh. Pada penelitian ini digunakan 7 kriteria yaitu nilai APSI, algoritma, pemrograman, basis data, pengantar teknologi informasi, jaringan komputer, dan sistem operasi. Hasil dari penelitian disimpulkan bahwa nilai akurasi metode TOPSIS sebesar 49,4\% yang sesuai dengan fakta dilapangan sedangkan metode AHP sebesar $41,4 \%$. Untuk ketidaksesuaian dilapangan metode TOPSIS sebesar 50,6\% sedangkan Metode AHP 58.6\%.

\section{METODE PENELITIAN}

Metode yang digunakan dalam rancang bangun sistem pendukung keputusan pemilihan mata kuliah peminatan adalah menggunakan metode iterative. [8]Metode iterative adalah metode dimana setiap tahapan atau fase pengembangan sistem dilaksanakan dengan memakai teknik pengulangan, dimana suatu proses dapat dilaksanakan secara berulang-ulang sampai mendapatkan hasil yang maksimal. [8] Adapun beberapa tahapan di dalam metode iterative adalah sebagai berikut :

1. Tahap Perencanaan Sistem

Pada tahap ini, dilakukan pendefinisian dari permasalahan yang ada untuk menentukan ruang lingkup, menentukan metodologi pengembangan aplikasi yang digunakan.

2. Tahap Analisis Sistem

Pada tahap ini, dilakukan analisis pada sistem yang telah ada dengan mengidentifikasi permasalahan, penentuan tujuan dari perbaikan sebuah sistem, dan mengidentifikasi kebutuhan pengguna.

3. Tahap Perancangan Sistem

Tahap ini menyatakan bagaimana membuat rancangan sistem dengan menggambarkan sebuah model sistem untuk menyelesaikan permasalahan.

4. Tahap Pembuatan Sistem

Pada tahap ini, dilakukan pembuatan sistem baru (hardware dan software) dengan alat bantu yang digunakan antara lain Netbeans IDE 8.2 sebagai aplikasi pengembang dan My $S Q L$ sebagai Sistem Manajemen Basis Data, serta bahasa pemrograman yang digunakan adalah bahasa java.

5. Tahap Implementasi Sistem

Pada tahap ini, dilakukan penginstalan database dan aplikasi desktop, serta pelatihan bagi pengguna aplikasi dan konversi ke sistem yang baru.

6. Tahap Pemeliharaan Sistem

Tahapan pemeliharaan sistem mencakup seluruh proses yang diperlukan untuk menjamin kelangsungan, kelancaran, dan penyempurnaan sistem yang telah dioperasikan. 


\section{HASIL DAN PEMBAHASAN}

\subsection{Implementasi Fuzzy}

Menentukan alternatif yang akan digunakan untuk sistem pendukung keputusan. Dalam penelitian ini terdapat 3 alternatif peminatan yaitu: A1: pengembangan game dan mobile platform, A2: komputasi ilmiah A3: adalah jaringan komputer. Selanjutnya menentukan rating kecocokan setiap alternatif yaitu:
1: Kurang Berpengaruh
2: Cukup Berpengaruh
3: Sangat Berpengaruh

\subsection{Implementasi SAW (Simple Additive Weighting)}

Tahap awal implementasi SAW (Simple Additive Weighting) adalah dengan menentukan kriteria yang dibutuhkan. Kriteria yang dibutuhkan merupakan nilai - nilai mata kuliah yang telah ditempuh mahasiswa program studi Teknik Informatika STMIK XYZ pada semester 1- 4. Mata kuliah yang dipilih merupakan mata kuliah prasyarat untuk pengambilan mata kuliah peminatan. Selain itu, ada mata kuliah yang cocok untuk dijadikan kriteria. Maka, terdapat 9 kriteria untuk pengambilan keputusan yang dapat dilihat pada Tabel 1.

Tabel 1. Kriteria Pengambil Keputusan

\begin{tabular}{|c|l|}
\hline Kriteria & Keterangan \\
\hline C1 & Pemrograman Berorientasi Objek \\
\hline C2 & Sistem Basis Data \\
\hline C3 & Basis Data Terapan \\
\hline C4 & Matematika Diskrit \\
\hline C5 & Aljabar Linear \& Matriks \\
\hline C6 & Pemrograman Game \\
\hline C7 & Pemrograman Aplikasi Bergerak \\
\hline C8 & Statistika \& Probabilitas \\
\hline C 9 & Jaringan Komputer \\
\hline
\end{tabular}

Tahap selanjutnya adalah menentukan bobot berdasarkan nilai mata kuliah. Bobot untuk nilai mata kuliah dapat dilihat pada Tabel 2.

Tabel 2. Bobot Nilai

\begin{tabular}{|c|c|l|}
\hline Range Nilai & Bobot & Keterangan \\
\hline A atau A- & 5 & Sangat Baik \\
\hline B+ atau B & 4 & Baik \\
\hline B- atau C+ & 3 & Cukup \\
\hline C & 2 & Kurang \\
\hline D & 1 & Sangat Kurang \\
\hline
\end{tabular}

Tahap selanjutnya adalah menentukan rating kecocokan setiap alternative pada setiap kriteria berdasarkan bobot nilai. Rating kecocokan setiap alternative dapat dilihat pada Tabel 3. 
Tabel 3. Rating Kecocokan Setiap Alternatif

\begin{tabular}{|c|c|c|c|c|c|c|c|c|c|}
\hline Alternatif & \multicolumn{10}{|c|}{ Kriteria } \\
\hline & C1 & C2 & C3 & C4 & C5 & C6 & C7 & C8 & C9 \\
\hline A1 & 5 & 5 & 4 & 2 & 2 & 5 & 5 & 3 & 3 \\
\hline A2 & 3 & 3 & 3 & 5 & 5 & 2 & 2 & 5 & 2 \\
\hline A3 & 3 & 4 & 5 & 4 & 4 & 3 & 3 & 4 & 5 \\
\hline
\end{tabular}

Tahap berikutnya adalah menentukan nilai vektor bobot berdasarkan tingkat kepentingan masing masing kriteria. Nilai vektor bobot dapat dilihat pada Tabel 4.

Tabel 4. Nilai Vektor Bobot

\begin{tabular}{|l|c|c|c|c|c|c|c|c|c|}
\hline Kriteria & $\mathrm{C} 1$ & $\mathrm{C} 2$ & $\mathrm{C} 3$ & $\mathrm{C} 4$ & $\mathrm{C} 5$ & $\mathrm{C} 6$ & $\mathrm{C} 7$ & $\mathrm{C} 8$ & C9 \\
\hline Bobot & 2 & 2 & 2 & 2 & 3 & 3 & 2 & 2 & 3 \\
\hline
\end{tabular}

Tahap selanjutnya adalah membuat matriks keputusan berdasarkan kriteria. Hal ini dilakukan dengan melakukan normalisasi matriks proses normalisasi matriks keputusan (X) ke suatu skala yang didapat diperbandingkan dengan semua rating alternatif yang ada dan jika nilai terbesar adalah nilai terbaik (benefit). Hasil perhitungan nilai $\mathrm{X}$ dan nilai normalisasi $\mathrm{R}$ dapat dilihat sebagai berikut:

$$
\begin{array}{rccccccccc}
\mathrm{X}= & 5 & 4 & 4 & 2 & 2 & 5 & 4 & 3 & 3 \\
& 3 & 3 & 3 & 5 & 5 & 2 & 2 & 5 & 2 \\
& 3 & 4 & 4 & 4 & 4 & 3 & 3 & 4 & 5 \\
1 & 1 & 1 & 0,4 & 0,4 & 1 & 1 & 0,6 & 0,6 \\
0,6 & 0,75 & 0,75 & 1 & 1 & 0,4 & 0,5 & 1 & 0,4 \\
0,6 & 1 & 1 & 0,8 & 0,8 & 0,6 & 0,75 & 0,8 & 1
\end{array}
$$

Selanjutnya adalah menghitung nilai preferensi untuk setiap alternatif (Vi) dengan rumus. Hasil dari perhitungan nilai preferensi sebagai berikut:

$$
\begin{aligned}
& \text { V1 }=(1)(3)+(1)(2)+(1)(2)+(0,4)(3)+(0,4)(3)+(1)(1)+(1)(2)+(0,6)(3)+(0,6)(2)=15,4 \\
& \text { V2 }=(0,6)(3)+(0,75)(2)+(0,75)(2)+(1)(3)+(1)(3)+(0,4)(1)+(0,5)(2)+(1)(3)+(0,4)(2)=16 \\
& \text { V3 }=(0,6)(3)+(1)(2)+(1)(2)+(0,8)(3)+(0,8)(3)+(0,6)(1)+(0,75)(2)+(0,8)(3)+(1)(2)=17,11
\end{aligned}
$$

Berdasarkan perhitungan nilai preferensi dapat diketahui bahwa V3 memiliki nilai terbesar dibandingkan dengan V1 dan V2 dengan nilai 17,11. Dengan demikian alternatif A3 adalah alternatif yang terpilih sebagai alternatif terbaik. Alternatif A3 merupakan peminatan Jaringan Komputer

\subsection{Implementasi Sistem}

Sistem pendukung keputusan pemilihan peminatan yang telah dibuat menggunakan aplikasi MySQL untuk pembuatan databasenya. Terdapat 2 buah tabel dimana tabel pertama merupakan tabel Mahasiswa yang berisi NPM, Nama, dan nilai-nilai mata kuliah kriteria pendukung keputusan. Sedangkan tabel kedua berisi data NPM, nilai alternatif 1, alternatif 2, alternatif 3, dan peminatan alternatif dengan nilai terbesar. Sistem dirancang menggunakan aplikasi Netbeans IDE 8.2 dan memiliki 3 buah JFrame Form utama yaitu:

a. JFrame Form Input Data Mahasiswa

JFrame Form Input Data Mahasiswa digunakan untuk menyimpan, merubah, dan menghapus data mahasiswa. Data yang dimasukkan adalah NPM, Nama, dan 9 nilai mata kuliah 
yang dijadikan kriteria pengambil keputusan. JFrame Form Input Data Mahasiswa dapat dilihat pada Gambar 1.

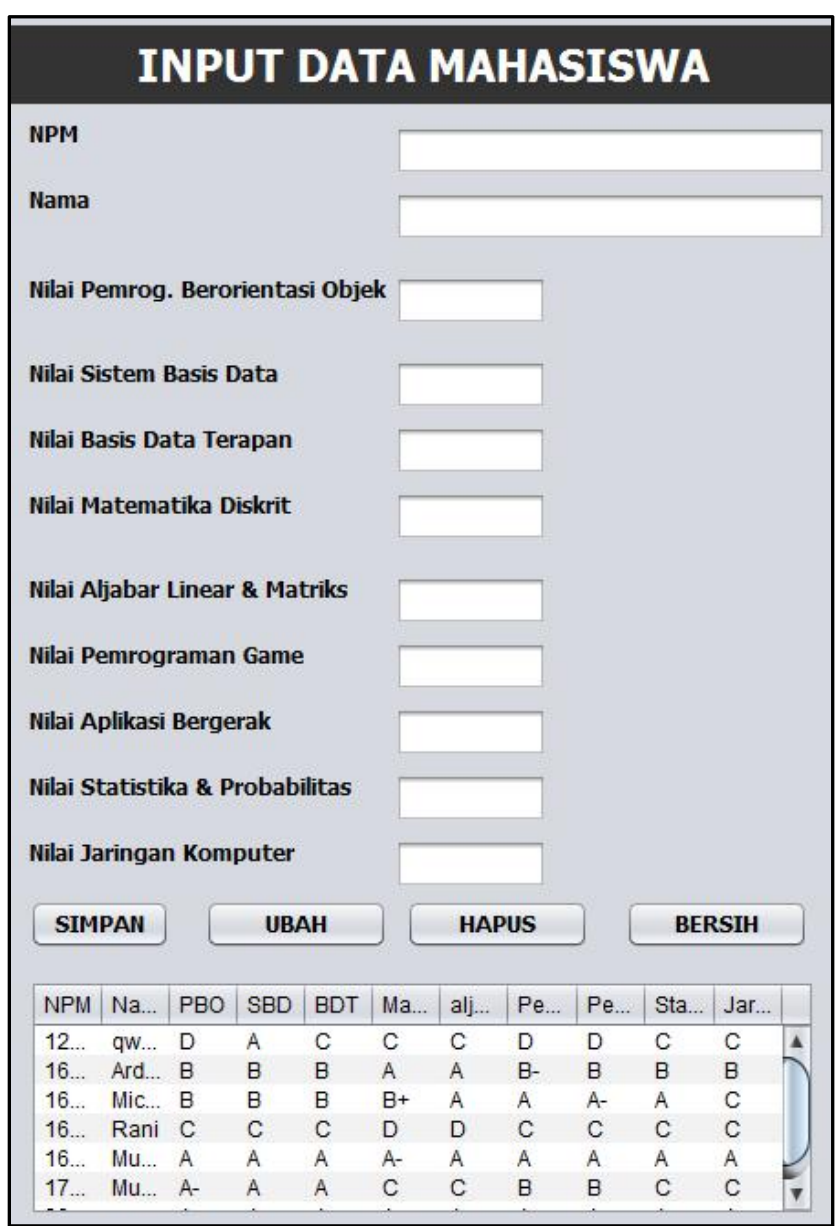

Gambar 1. JFrame Form Input Data Mahasiswa

\section{b. JFrame Form Menu SPK}

JFrame Form menu SPK menampilkan tabel mahasiswa yang berisi data mahasiwa dan nilai yang telah diinput sebelumnya. Cara mengetahui nilai total alternatif A1, A2, dan A3 dengan cara pengguna memilih mahasiswa di tabel mahasiwa, kemudian menekan tombol PROSES sehingga akan muncul nilai matriks $X$, nilai matriks $R$, nilai bobot, total nilai alternatif A1, A2, A3, serta menampilkan nilai alternatif terbesar dan peminatan yang terpilih. Pengguna juga dapat menyimpan hasil SPK dengan menekan tombol SIMPAN. JFrame Form Menu SPK dapat dilihat pada Gambar 2. 


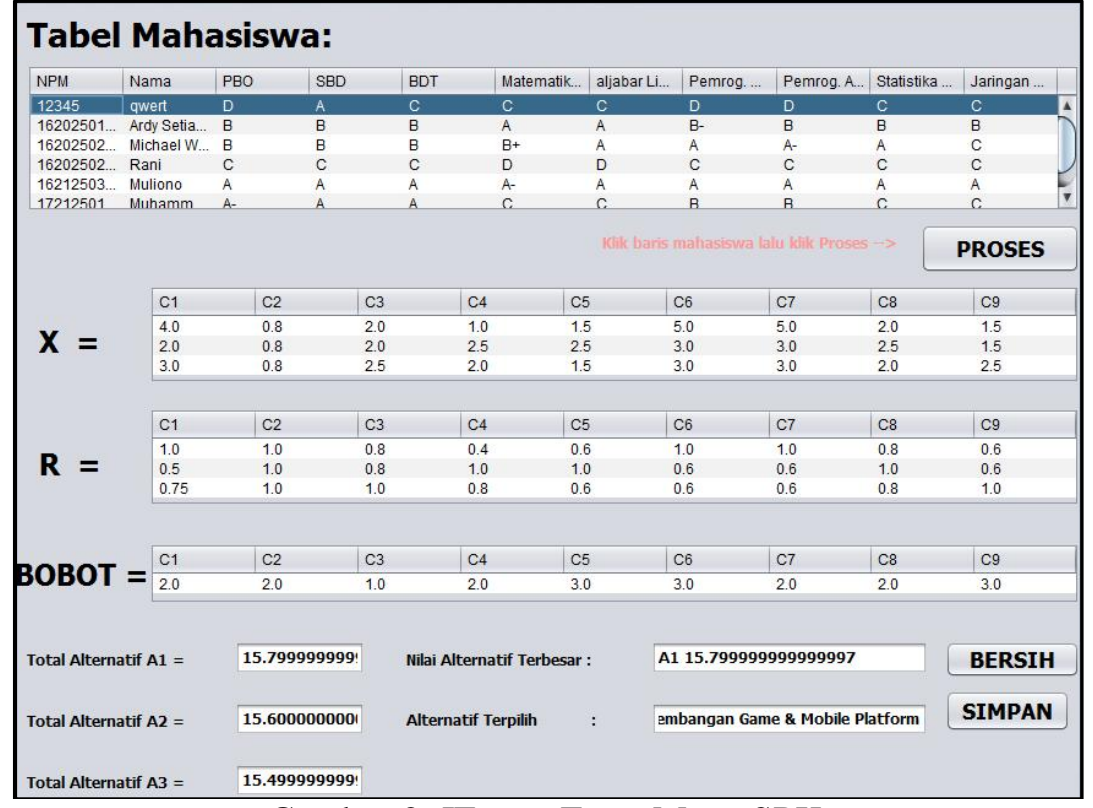

Gambar 2. JFrame Form Menu SPK

c. JFrame Form Tampil Nilai SPK

JFrame Form Tampil Nilai SPK menampilkan tabel yang berisi data NPM, total Nilai Alternatif A1, A2, A3, serta Referensi peminatan berdasarkan nilai alternatif terbesar. JFrame Form Tampil Nilai SPK dapat dilihat pada Gambar 3.

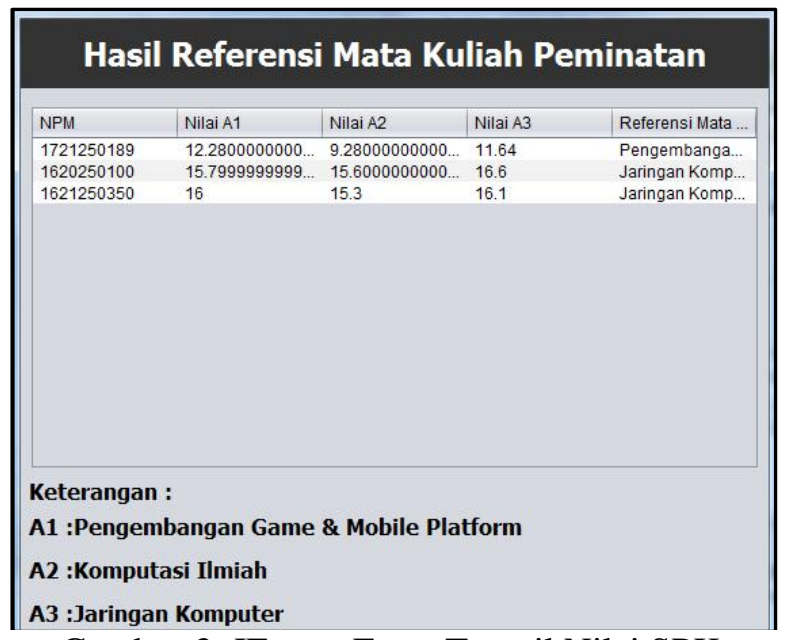

Gambar 3. JFrame Form Tampil Nilai SPK

\section{KESIMPULAN}

Sistem pendukung keputusan pemilihan peminatan program studi Teknik Informatika ini telah dapat membantu mahasiswa program studi Teknik Informatika untuk mengambil keputusan peminatan apa yang akan mereka ambil pada semester 5 berdasarkan hasil nilai dari 9 mata kuliah yang dijadikan kriteria. Selain itu, sistem ini juga dapat melakukan update 
terhadap nilai yang diinput mahasiswa sehinggan hasil dari sistem pendukung keputusan berdasarkan nilai terbaru yang diperoleh oleh mahasiswa.

\section{SARAN}

Sistem pendukung keputusan pemilihan peminatan program studi Teknik Informatika ini dapat dikembangkan lebih lanjut dengan menambahkan kriteria selain nilai mata kuliah seperti kriteria IPK, minat, dll. Sistem juga dapat dikembangkan dengan menambahkan soal soal yang harus dijawab oleh mahasiswa sehingga hasil dari jawaban mahasiswa terhadap soalsoal tersebut dapat menentukan peminatan yang cocok. Selain itu dapat pula dikembangkan dengan metode lain seperti AHP atau metode yang lain sehingga dapat diketahui metode mana yang paling cocok untuk pemilihan peminatan program studi Teknik Informatika.

\section{UCAPAN TERIMA KASIH}

Penulis mengucapkan terima kasih kepada kepala program studi Teknik Informatika STMIK XYZ beserta para dosen dan mahasiswa yang telah membantu dalam pengambilan data pada penelitian ini.

\section{DAFTAR PUSTAKA}

[1] Teknik Informatika, http://mdp.ac.id/jurusan/teknik-informatika, Diakses Tanggal 1 November 2018.

[2] Kerangka Kualifikasi Nasional Indonesia (KKNI), http://www.kkni-kemenristekdikti.org/, Diakses Tanggal 29 November 2018.

[3] Kusumadewi Sri, 2007, Fuzzy Multi-Attribute Decision Making, Graha Ilmu, Yogyakarta.

[4] Nofriansyah, Dicky. 2014, Konsep Data Mining Sistem Pendukung Keputusan, Deepublish (CV Budi Utama), Yogyakarta.

[5] Yumarlin MZ. 2016, Sistem Pendukung Keputusan Konsentrasi dan Peminatan Prodi Teknik Informatika Universitas Janabadra Yogyakarta, Citec Journal, Nomor 4, Vol. 3.

[6] Muhammad Ibrohim dan Sumiati. 2016, Decision Support System for Determining The Scholarship Recipients Using Simple Additive Weighting (SAW), International Journal of Computer Applications, No. 2, Vol 151.

[7] Adi Suwarno. 2016, Perbandingan Metode AHP Dengan Metode MADM Topsis Untuk Menentukan Matakuliah Peminatan Bagi Mahasiswa, Jurnal Teknologi Pelita Bangsa SIGMA, Nomor 1, Vol.4.

[8] Whitten, Bentley dan Ditman 2004, Metode Desain dan Analisis Sistem: Edisi ke-6, Andi Offset, Yogyakarta. 